\title{
Risky sexual behavior in adolescents does not depend on the level of knowledge about HIV/AIDS?
}

O comportamento sexual de risco em adolescentes independe do nível de conhecimento sobre HIV/AIDS?

¿Es el comportamiento sexual de riesgo en los adolescentes independiente del nivel de conocimiento sobre el VIH/SIDA?

Received: 10/06/2021 | Reviewed: 10/13/2021 | Accept: 10/17/2021| Published: 10/19/2021

Jéssica Kelly Ramos Cordeiro

ORCID: https://orcid.org/0000-0002-2856-6423

Universidade Estadual da Paraíba, Brasil

E-mail: jessicaenfermeira@outlook.com

Waleska Fernanda Souto Nóbrega

ORCID: https://orcid.org/0000-0001-8140-4063

Universidade Estadual da Paraíba, Brasil

E-mail: drawaleskasouto@gmail.com

Milena Edite Casé de Oliveira

ORCID: https://orcid.org/0000-0003-2266-5890

Universidade Federal da Paraíba, Brasil E-mail: milacdo1@gmail.com

Kedma Anne Lima Gomes

ORCID: https://orcid.org/0000-0001-6720-011X

Universidade Federal da Paraíba, Brasil E-mail: kalg2010@hotmail.com

Tiago Almeida de Oliveira

ORCID: https://orcid.org/0000-0003-4147-7721

Universidade Estadual da Paraíba, Brasil

E-mail: tadolive@cct.uepb.edu.br

Ângelo Giuseppe Roncalli da Costa Oliveira

ORCID: https://orcid.org/0000-0001-5311-697X Universidade Federal do Rio Grande do Norte, Brasil E-mail: angelo.oliveira@ufrn.br

\begin{abstract}
Objective: to assess the knowledge and practices of adolescent students in relation to HIV/AIDS and other STIs. Methods: this is a cross-sectional study, with a quantitative approach, which included twelve public schools from seven cities in Rio Grande do Norte, with a sample of 623 individuals. Two electronic and interactive questionnaires were used for data collection. Data processing was performed using SPSS 25.0® and Stata 14.0. For the analysis of associated factors, the Item Response Theory was used. The project of this study was approved by the Research Ethics Committee of the Federal University of Rio Grande do Norte, Protocol No. 99473118.2.0000.5292. Results: The participants who achieved the highest means of knowledge level were female $(6.04 \pm 4.47)$, with a partner $(6.13 \pm$ $4.49)$, white $(6.10 \pm 4.46)$ and received financial assistance from the government $(6.72 \pm 4.40)$. Most teenagers reported that they had already had their first sexual intercourse. Of those who continued to have sex in the last 6 months, only $31.3 \%$ used a condom. Final considerations: Adolescents have a considerable level of knowledge about the prevention of HIV/AIDS and other STIs, but their sexual practices do not follow the recommended preventive measures.
\end{abstract}

Keywords: Adolescent; Sexually transmitted diseases; Acquired immunodeficiency syndrome; Health education.

\section{Resumo}

Objetivo: avaliar os saberes e práticas dos adolescentes escolares em relação ao HIV/AIDS e outras IST. Métodos: trata-se de um estudo transversal, com abordagem quantitativa, que incluiu doze escolas públicas de sete cidades do Rio Grande do Norte, com uma amostragem de 623 indivíduos. Foram utilizados dois questionários eletrônicos e interativos para coleta de dados. O tratamento dos dados foi realizado no SPSS 25.0® e pelo Stata 14.0. Para a análise dos fatores associados, foi utilizada a Teoria da Resposta ao Item. O projeto deste estudo foi aprovado pelo Comitê de Ética em Pesquisa da Universidade Federal do Rio Grande do Norte, Protocolo no 99473118.2.0000.5292. Resultados: Os participantes que alcançaram as maiores médias de nível de conhecimento eram do sexo feminino $(6,04 \pm 4,47)$, 
com companheiro $(6,13 \pm 4,49)$, brancos $(6,10 \pm 4,46)$ e recebiam auxílio financeiro do governo $(6,72 \pm 4,40)$. A maioria dos adolescentes relataram que já haviam tido sua primeira relação sexual. Daqueles que mantiveram a prática sexual nos últimos 6 meses, apenas 31,3\% usaram preservativo. Considerações finais: Os adolescentes apresentam um nível de conhecimento considerável sobre a prevenção do HIV/AIDS e outras IST, mas suas práticas sexuais não seguem as medidas preventivas recomendadas.

Palavras-chave: Adolescente; Doenças sexualmente transmissíveis; Síndrome da imunodeficiência adquirida; Educação em saúde.

\section{Resumen}

Objetivo: evaluar los conocimientos y prácticas de los estudiantes adolescentes en relación con el VIH/SIDA y otras ITS. Métodos: se trata de un estudio transversal, con enfoque cuantitativo, que incluyó a doce escuelas públicas de siete ciudades de Rio Grande do Norte, con una muestra de 623 individuos. Se utilizaron dos cuestionarios electrónicos e interactivos para la recopilación de datos. El tratamiento de los datos se realizó con SPSS 25.0® y Stata 14.0. Para el análisis de factores asociados se utilizó la Teoría de Respuesta al Ítem. El proyecto de este estudio fue aprobado por el Comité de Ética en Investigación de la Universidad Federal de Rio Grande do Norte, Protocolo No. 99473118.2.0000.5292. Resultados: Los participantes que alcanzaron el mayor nivel medio de conocimiento fueron mujeres $(6,04 \pm 4,47)$, con pareja $(6,13 \pm 4,49)$, blancos $(6,10 \pm 4,46)$ y recibieron ayuda económica del gobierno $(6,72 \pm 4,40)$. La mayoría de los adolescentes informaron que ya habían tenido su primera relación sexual. De los que continuaron teniendo relaciones sexuales en los últimos 6 meses, solo el 31,3\% usó condón. Consideraciones finales: Los adolescentes tienen un nivel considerable de conocimiento sobre la prevención del VIH/SIDA y otras ITS, pero sus prácticas sexuales no siguen las medidas preventivas recomendadas.

Palabras clave: Adolescente; Enfermedades sexualmente transmisibles; Síndrome de inmunodeficiencia adquirida; Educación para la salud.

\section{Introduction}

Adolescence is a period of life marked by intense physical, psychological, social and cognitive changes (Neves et al., 2017). It is at this stage where basic patterns of behavior are established that will have repercussions throughout life, such as the beginning of sexual activities (Fonseca et al., 2018).

The National School Health Survey (PeNSE, in Portuguese) (2016) conducted in Brazil, considers that over the years, teenagers have been starting sexual activities earlier, with an average age between 14 and 15 . In addition, most of these young people present other risk factors for the development of unhealthy sexual behaviors, such as: situations of social vulnerability, lack of knowledge about sexuality and low access to health services (Costa et al., 2020).

The process of sexual education permeates several environments, such as family, social and school (Cabrera-García et al., 2018). In view of this scenario, the importance of sexual education in the school environment is emphasized, because this knowledge will enable the development of ethical values, making young people able to make healthy choices for themselves and their partners (Zompero et al., 2018).

In addition, strengthening family ties, such as: (i) having at least one meal with parents or guardians most of the week and (ii) the knowledge of parents or guardians about what teenagers do in their spare time, is also considered a protective factor for healthy sex life among young people and teenagers (Malta et al., 2014).

The ignorance of the risks in the face of Sexually Transmitted Infections (STIs) reflects important gaps in the sexual life of individuals, such as non-adhering to prevention methods, such as condom use, and is therefore considered a public health problem (Ferrari, Peres \& Nascimento, 2018; Pinto et al., 2018).

These repercussions represent a great impact on the sexual and reproductive health of teenagers, since it can trigger other diseases, such as pelvic inflammatory disease, cervical cancer, female sterility, postpartum infections, among others (Costenaro et al., 2020).

Regarding socioeconomic status, individuals with better financial status have greater access to knowledge about forms of transmission and prevention of HIV infection (Brazil, 2011). Although national studies seek to trace the profile of the knowledge, attitudes and practices of teenagers about STIs, there is a scarcity of data on areas with low or medium Human 
Development Index (HDI) and high social inequality (Brazil, 2010).

Thus, it is understood the importance of analyzing the risk factors for the health of teenagers, considering their social dynamics, especially in a country marked by high rates of social inequalities. This information is indispensable for the improvement of policies for the prevention and promotion of sexual health. Thus, the aim of this article was to evaluate the knowledge and practices of school teenagers in relation to HIV/AIDS and other STIs in the interior of Northeastern Brazil.

\section{Methodology}

This was a cross-sectional, observational and quantitative study of the CAP survey (Knowledge, Attitude and Practice). The research took place in 12 public high schools, located in the urban area of 7 cities in the interior of the State of Rio Grande do Norte. Students between 14 and 19 years old who were enrolled in regular high school were included. The exclusion criterion considered students who were transferred to another educational institution during data collection.

The sample was calculated considering the prevalence of adequate knowledge of $31.4 \%$, an absolute margin of error of $5 \%$, the design effect of 1.5 (as a function of cluster sample use in 1 stage) and a friction rate of $20 \%$, suggesting a sample $\mathrm{N}$ of 623 (Cordeiro et al., 2017).

Within the conglomerates, schools were considered as Primary Sampling Units. Once the sample size was defined, a draw was made using the Proportional Probability to Size (PPT) technique, with reference to the number of students enrolled. Then, the sample was selected by systematic random sampling, based on lists provided by school administrations. Thus, a combination of probabilistic sampling techniques was performed hierarchically (Etikan \& Bala, 2017).

Two questionnaires were applied in electronic format. The first had questions related to socioeconomic data, such as: gender, age, race, income, education, marital status, number of children, parents' schooling, responsible for family support and religion. Subsequently, the "Questionnaire for the evaluation of STD/AIDS prevention programs" was applied, used by the Ministry of Health and composed of 50 questions on the proposed theme.

Data collection took place during the months of April to June 2019, in the computer rooms of the selected educational institutions. The application was directed by the main author and three volunteer researchers, previously calibrated.

The two electronic questionnaires were inserted in the computers of the schools themselves, where the research subjects had access on scheduled days and times, allowing them to be answered in a self-applied and individual way, preserving the privacy of individuals.

Data were processed at the Statistical Package for the Social Sciences (SPSS) 25.0® and Stata 14.0. For the execution of the association tests, the nature of the independent variables and dependent variables were observed, expressed by the number of correct answers in the questionnaire. The categorical independent variables were submitted to the Chi-square/Fisher test. The quantitative ones, such as age and number of children, were categorized by tertile or median and were submitted to the same statistical test.

For the analysis of the associated factors, the degree of knowledge about STIs was considered as a dependent variable, calculated by correctly the ten questions related to the teenagers' knowledge about the theme (Chart 1). To establish the weight of each question, the data related to the answers were submitted to analysis by the Item Response Theory (IRT), which allows establishing the discriminatory power of a given question in a questionnaire, considering a given set of data. The coefficient of discriminatory power found with significant value for each question was then used as weight and a weighted score was calculated for the degree of knowledge (Moita, 2004). The independent variables were constituted by the socioeconomic/demographic data of the teenagers. 
Board 1 - Characterization of dependent variables related to QSAP knowledge according to code, nature and values.

\begin{tabular}{|c|c|c|c|}
\hline Code & Nature & Issues (Variables) & Values \\
\hline AIDSCAM & Nominal categorical & $\begin{array}{l}\text { Q4- Do you think a person can get aids if they } \\
\text { have sex without a condom? }\end{array}$ & $\frac{0-\mathrm{NO}}{1-\mathrm{YES}}$ \\
\hline AIDSCUTLERY & Nominal categorical & $\begin{array}{l}\text { Q5-Do you think a person can catch AIDS if they } \\
\text { use the same cutlery, plates and glasses as } \\
\text { someone who has AIDS? }\end{array}$ & $\frac{0-\mathrm{YES}}{1-\mathrm{NO}}$ \\
\hline AIDSKISS & Nominal categorical & $\begin{array}{l}\text { Q6-Do you think a person can get AIDS if they } \\
\text { use the same bathroom that someone who has } \\
\text { AIDS uses? }\end{array}$ & $\begin{array}{c}0-\mathrm{YES} \\
1-\mathrm{NO}\end{array}$ \\
\hline AIDSRESTROOM & Nominal categorical & $\begin{array}{l}\text { Q7-Do you think a person can catch aids if they } \\
\text { kiss on the mouth a person who has the AIDS } \\
\text { virus? }\end{array}$ & $\frac{0-\mathrm{YES}}{1-\mathrm{NO}}$ \\
\hline AIDSPREGNANCY & Nominal categorical & $\begin{array}{l}\text { Q8-During pregnancy or childbirth, the mother } \\
\text { can pass the AIDS virus to the child? }\end{array}$ & $\frac{0-\mathrm{NO}}{1-\mathrm{YES}}$ \\
\hline AIDSMILK & Nominal categorical & $\begin{array}{l}\text { Q9-A baby can get AIDS when receiving breast } \\
\text { milk from a woman who has the AIDS virus? }\end{array}$ & $\frac{0-\mathrm{NO}}{1-\mathrm{YES}}$ \\
\hline AIDSINSECT & Nominal categorical & $\begin{array}{l}\text { Q10-A person can catch AIDS by bites of } \\
\text { mosquito insects? }\end{array}$ & $\begin{array}{c}0-\mathrm{YES} \\
1-\mathrm{NO}\end{array}$ \\
\hline AIDSBLOOD & Nominal categorical & $\begin{array}{l}\text { Q11-A person can get AIDS if they receive blood } \\
\text { contaminated by the AIDS virus? }\end{array}$ & $\begin{array}{c}0-\mathrm{NO} \\
1-\mathrm{YES}\end{array}$ \\
\hline AIDSSYRINGE & Nominal categorical & $\begin{array}{l}\text { Q12-A person can become infected with the } \\
\text { AIDS virus if they use the same syringe and } \\
\text { needle that someone else used? }\end{array}$ & $\frac{0-\mathrm{NO}}{1-\mathrm{YES}}$ \\
\hline
\end{tabular}

Source: Search data (2020).

In this sense, the project response theory (PRT) has a strong knowledge of the underlying structure to make assumptions at the item level (Andrade et al., 2000). PRT is considered a modern psychometric theory because it focuses on each item of the measuring tool and assumes that the performance of a given test can be explained by an individual, and not by directly observable characteristics, called latent characteristics. Its growth adds complex theoretical baggage to behavioral and social sciences measures, which must be researched and applied to improve the resulting tests, for example, to quantify knowledge about sexually transmitted diseases (Rodrigues et al., 2013).

Because it is a research involving human beings, the recommendations of Resolution 466/2012 of the National Health Council were followed. All interviewees signed the Free and Informed Consent Form and/or Free and Informed Consent Form, when it applied. The project of this study was evaluated by the Research Ethics Committee of the Federal University of Rio Grande do Norte - HUOL/UFRN, Protocol N 99473118.2.0000.5292.

\section{Results and Discussion}

The study included 623 school teenagers, with predominance of females (54.7\%), average age of $16.4 \pm 1.13$ years old, without a partner $(94.4 \%)$ and non-whites (56.9). Table 1 shows the relationship between the score of correct answers regarding HIV/AIDS knowledge and sociodemographic data, using the value weighted by the Item Response Theory (ITT) technique via logistic model for two-parameter STIs (Table 1). Thus, the average, the standard deviation (D.P.) and the median refer to the variable: degree of knowledge. As for gender, there was little difference in the average number of correct answers, with a higher percentage of females $(6.04$ 14.47). The highest average scans were also obtained in those with a partner $(6.13 \pm 4.49)$, attending the 2 nd year $(6.01 \pm 4.47)$ and white $(6.10 \pm 4.46)$. Those who lived alone $(9.99 \pm 0.19)$ and had children $(6.71 \pm 5.16)$ also had higher averages of hit (Table 1).

The mother also had a higher average of correct answers, those whose parents are not married (5.84 \pm 4.52$)$, those who had at least the complete elementary level $(6.34 \pm 4.41)$ and the father in higher education $(7.35 \pm 4.00)$. Individuals who worked 
during the studies $(6.66 \pm 4,31)$, who had their brother as the main responsible for family support $(7.36 \pm 5,10)$ and who received financial assistance from the federal government (6.72 \pm 4.40$)$ also had a higher average of correct answers (Table 1).

Table 1 - Measures of central tendency and dispersion of adolescents' knowledge and practices about HIV/AIDS in relation to the sociodemographic/economic data of the participants, Natal/RN, 2020.

\begin{tabular}{|c|c|c|c|c|c|c|c|}
\hline \multirow[b]{2}{*}{ Variable } & \multirow[b]{2}{*}{$\mathbf{N}$} & \multirow[b]{2}{*}{$\%$} & \multirow[b]{2}{*}{ Média } & \multirow[b]{2}{*}{ SD } & \multirow[b]{2}{*}{ Mediana } & \multicolumn{2}{|c|}{ IC95\% } \\
\hline & & & & & & L.I. & L.S. \\
\hline \multicolumn{8}{|l|}{ Gender } \\
\hline Male & 282 & $45.3(39.5-51.1)$ & 5.78 & 4.56 & 9.12 & 5.24 & 6.32 \\
\hline Female & 341 & $54.7(49.4-60.0)$ & 6.04 & 4.47 & 9.12 & 5.56 & 6.52 \\
\hline \multicolumn{8}{|l|}{ Marital status } \\
\hline With mate & 35 & $5.6(0.0-13.2)$ & 6.13 & 4.49 & 9.26 & 4.45 & 7.81 \\
\hline No mate & 588 & $94.4(92.5-96.3)$ & 5.97 & 3.23 & 9.12 & 2.88 & 9.05 \\
\hline \multicolumn{8}{|l|}{ Schooling } \\
\hline $1^{\text {st }}$ year of high school & 256 & $41.1(35.1-47.1)$ & 5.89 & 4.56 & 9.12 & 5.33 & 6.46 \\
\hline $2^{\text {nd }}$ year of high school & 206 & $33, .1(26.7-39.5)$ & 6.01 & 4.47 & 9.12 & 5.39 & 6.63 \\
\hline $3^{\text {rd }}$ year of high school & 161 & $25.8(19.0-32.6)$ & 5.87 & 4.52 & 9.12 & 5.17 & 6.58 \\
\hline \multicolumn{8}{|l|}{ Color/Race } \\
\hline Not White & 355 & $56.9(0.0-13.2)$ & 5.25 & 4.66 & 6.64 & 3.70 & 3.81 \\
\hline White & 268 & $43.0(37.1-48.9)$ & 6.10 & 4.46 & 9.12 & 5.56 & 6.64 \\
\hline \multicolumn{8}{|l|}{ Religion } \\
\hline Adept & 541 & $86.8(83.9-89.7)$ & 5.75 & 4.55 & 7.66 & 4.48 & 7.01 \\
\hline Not adept & 82 & $13.2(5.9-20.5)$ & 5.65 & 4.50 & 8.85 & 4.65 & 6.65 \\
\hline \multicolumn{8}{|l|}{ Attendance to religious } \\
\hline \multicolumn{8}{|l|}{ Ceremonies } \\
\hline Attends & 451 & $72.4(68.3-76.5)$ & 5.95 & 4.53 & 9.12 & 5.26 & 6.64 \\
\hline Does not attend & 172 & $27.6(20.9-34.3)$ & 5.91 & 4.53 & 9.10 & 5.15 & 6.67 \\
\hline \multicolumn{8}{|l|}{ Who lives with you? } \\
\hline Husband/wife, mate & 24 & $3.9(0.0-11.6)$ & 5.34 & 4.67 & 5.46 & 3.15 & 7.52 \\
\hline I live alone & 2 & $0.3(0.0-7.9)$ & 9.99 & 0.19 & 9.99 & 8.28 & 11.69 \\
\hline Other relatives, friends & 63 & $10.1(2.7-17.5)$ & 6.32 & 4.43 & 8.95 & 4.43 & 8.20 \\
\hline Father and/or mother & 534 & $85.7(82.6-88.6)$ & 5.91 & 4.52 & 9.12 & 5.53 & 6.29 \\
\hline \multicolumn{8}{|c|}{$\begin{array}{l}\text { Do you have any children? How } \\
\text { many? }\end{array}$} \\
\hline Four or more & 3 & $0.5(0.0-8.5)$ & 6.71 & 5.16 & 9.24 & 0.00 & 19.53 \\
\hline One to three & 61 & $9.8(2.3-17.1)$ & 5.82 & 4.66 & 9.01 & 3.52 & 8.13 \\
\hline I don't have any children & 559 & $89.7(87.2-92.2)$ & 5.93 & 4.51 & 9.12 & 5.55 & 6.31 \\
\hline \multicolumn{8}{|l|}{ Marital status of parents } \\
\hline Married & 355 & $57.0(51.8-62.2)$ & 5.82 & 4.53 & 7.03 & 4.41 & 7.23 \\
\hline Not married & 268 & $43.0(37.1-48.9)$ & 5.84 & 4.52 & 9.12 & 5.37 & 6.32 \\
\hline \multicolumn{8}{|l|}{ Even when your mother } \\
\hline Studied? & & & & & & & \\
\hline You haven't studied & 13 & $2.1(0.0-9.9)$ & 4.23 & 4.52 & 1.20 & 1.50 & 6.95 \\
\hline From $1^{\text {st }}$ to $4^{\text {th }}$ grade of & 113 & $18.1(11.0-25.2)$ & 5.74 & 4.52 & 8.85 & 4.88 & 6.59 \\
\hline $\begin{array}{l}\text { Elementary education } \\
\text { Complete elementary school }\end{array}$ & 216 & $34.7(28.3-40.9)$ & 6.34 & 4.41 & 9.21 & 5.44 & 7.23 \\
\hline Complete high school & 193 & $31.0(24.5-37.5)$ & 6.10 & 4.54 & 9.18 & 5.00 & 7.20 \\
\hline Complete higher education & 27 & $4.3(0.0-12.0)$ & 6.25 & 4.64 & 9.09 & 3.41 & 9.09 \\
\hline I don't know & 61 & $9.8(2.3-17.3)$ & 5.00 & 4.54 & 1.42 & 3.84 & 6.16 \\
\hline Even when your father studie & & & & & & & \\
\hline Haven't studied & 44 & $7.1(0.0-14.7)$ & 5.71 & 4.59 & 8.99 & 4.32 & 7.11 \\
\hline $\begin{array}{l}\text { From } 1^{\text {st }} \text { to } 4^{\text {th }} \text { grade of } \\
\text { Elementary school }\end{array}$ & 144 & $23.1(16.2-30.0)$ & 5.88 & 4.51 & 9.12 & 5.13 & 6.63 \\
\hline Complete elementary school & 185 & $29.7(23.8-35.4)$ & 6.21 & 4.43 & 9.09 & 5.23 & 7.20 \\
\hline Complete high school & 110 & $17.7(10.6-24.8)$ & 6.37 & 4.55 & 9.31 & 4.83 & 7.91 \\
\hline Complete higher education & 18 & $2.9(0.0-10.4)$ & 7.35 & 4.00 & 9.48 & 4.28 & 10.43 \\
\hline I don't know & 44 & $7.1(0.0-14.7)$ & 5.11 & 4.60 & 1.81 & 4.28 & 5.94 \\
\hline What your home is like? & & & & & & & \\
\hline Not own & 155 & $24.9(18.0-31.6)$ & 6.20 & 4.24 & 6.95 & 2.90 & 9.49 \\
\hline Own & 468 & $75.1(71.2-79.0)$ & 6.04 & 4.51 & 9.12 & 5.63 & 6.45 \\
\hline $\begin{array}{l}\text { Have you worked or had any } \\
\text { activity during your studies? }\end{array}$ & & & & & & & \\
\hline No & 486 & $78.0(74.3-81.7)$ & 5.95 & 4.53 & 9.12 & 5.55 & 6.36 \\
\hline Yes, 1 to 3 years & 23 & $3.7(0.0-11.4)$ & 4.50 & 4.69 & 4.85 & 0.00 & 9.49 \\
\hline
\end{tabular}




\begin{tabular}{|c|c|c|c|c|c|c|c|}
\hline Yes, more than 3 years & 5 & $0.8(0.0-8.6)$ & 5.24 & 5.32 & 5.29 & 0.00 & 13.72 \\
\hline Yes, less than 1 year & 59 & $9.5(2.0-17.0)$ & 5.37 & 4.53 & 8.79 & 4.18 & 6.56 \\
\hline Yes, all the time & 50 & $8.0(0.5-15.5)$ & 6.66 & 4.31 & 9.39 & 5.38 & 7.94 \\
\hline \multicolumn{8}{|l|}{$\begin{array}{l}\text { Who is the main responsible for } \\
\text { the support of the family? }\end{array}$} \\
\hline Husband/wife & 13 & $2.1(0.0-9.9)$ & 5.48 & 4.68 & 9.12 & 2.65 & 8.30 \\
\hline Father or mother & 543 & $87.2(84.3-89.9)$ & 5.86 & 4.52 & 9.04 & 5.31 & 6.41 \\
\hline Brethren & 4 & $0.6(0.0-8.2)$ & 7.36 & 5.10 & 9.73 & 0.00 & 15.47 \\
\hline Other & 63 & $10.1(1.3-16.3)$ & 6.19 & 4.46 & 9.05 & 4.98 & 7.41 \\
\hline \multicolumn{8}{|l|}{$\begin{array}{l}\text { What is your family's average } \\
\text { monthly income today? }\end{array}$} \\
\hline $\begin{array}{l}\text { Has no income - lives on the } \\
\text { help of others }\end{array}$ & 12 & $1.9(0.0-9.6)$ & 5.18 & 4.88 & 5.22 & 2.08 & 8.28 \\
\hline Receives help from Social & & & & & & & \\
\hline $\begin{array}{l}\text { Programs of the Federal } \\
\text { Government }\end{array}$ & 48 & $7.7(0.2-15.2)$ & 6.72 & 4.40 & 9.36 & 5.42 & 8.03 \\
\hline Up to $\mathrm{R} \$ 510,00$ & 78 & $12.5(5.2-19.8)$ & 5.22 & 4.53 & 5.52 & 4.20 & 6.24 \\
\hline From $\mathrm{R} \$ 510.00$ to $\mathrm{R} \$ 1,530.00$ & 386 & $62.0(57.1-66.7)$ & 5.92 & 4.50 & 9.07 & 5.09 & 6.74 \\
\hline Over $\mathrm{R} \$ 1,530.00$ & 99 & $15.9(8.7-23.1)$ & 5.88 & 4.60 & 9.12 & 4.96 & 6.81 \\
\hline
\end{tabular}

SD - Standard Deviation

CI - Confidence Interval

Source: Search data (2020).

Table 2 shows variables in the family context and participation in educational activities related to STIs. Most teenagers did not have smokers (61\%) and alcoholics $(52.2 \%)$ in their family. The Internet is cited as the main means of acquiring knowledge regarding STIs $(83.8 \%)$. A significant portion of the interviewees reported having already participated in some educational action on sexual and reproductive health at school (65.7\%), with the majority of these actions conducted by teachers (27.1\%). A larger number also reported having received pamphlets on STIs prevention in the last year (51.5\%), however, most of the sample $(64.8 \%)$ reported not having received condoms. 
Table 2 - Distribution of absolute values and percentages of family context variables and participation in educational activities in relation to HIV/AIDS and other STIs, Natal/RN, 2020.

\begin{tabular}{|c|c|c|c|}
\hline Variable & Category & $\mathbf{N}$ & $\%(\mathrm{CI} 95 \%)$ \\
\hline \multirow[t]{2}{*}{ Someone smokes in your family? } & Yes & 243 & $39.0(32.9-45.1)$ \\
\hline & No & 380 & $61.0(56.1-65.9)$ \\
\hline \multirow{2}{*}{$\begin{array}{l}\text { Do you have any family members involved } \\
\text { with alcoholism? }\end{array}$} & Yes & 298 & $47.8(42.1-53.5)$ \\
\hline & No & 325 & $52.2(46.8-57.6)$ \\
\hline \multirow{4}{*}{$\begin{array}{l}\text { Which means of communication do you use } \\
\text { most to gain knowledge about HIV/AIDS } \\
\text { and other STIs? }\end{array}$} & Internet & 522 & $83.8(80.6-87.0)$ \\
\hline & Newspaper & 28 & $4.5(0.0-12.2)$ \\
\hline & Magazine & 6 & $1.0(0.0-9.0)$ \\
\hline & Television, Radio & 67 & $10.8(3.4-18.2)$ \\
\hline \multirow{2}{*}{$\begin{array}{l}\text { Have you participated in any educational } \\
\text { action on sexual and reproductive health in } \\
\text { your school? }\end{array}$} & No & 214 & $34.3(27.9-40.7)$ \\
\hline & Yes & 409 & $65.7(61.1-70.3)$ \\
\hline \multirow{4}{*}{$\begin{array}{l}\text { Who conducted the actions? (Only mark } \\
\text { this alternative if the answer to question } 19 \\
\text { was "YES") }\end{array}$} & PSE & 94 & $15.1(7.9-22.3)$ \\
\hline & Teachers & 169 & $27.1(20.4-33.8)$ \\
\hline & University Projects & 20 & $3.2(0.0-10.9)$ \\
\hline & Other social programs & 125 & $20.1(13.1-27.1)$ \\
\hline \multirow{2}{*}{$\begin{array}{l}\text { You have received informative pamphlets } \\
\text { about HIV/AIDS and other STIs in the last } \\
\text { year? }\end{array}$} & No & 302 & $48.5(42.9-54.1)$ \\
\hline & Yes & 321 & $51.5(46.0-57.0)$ \\
\hline \multirow[t]{2}{*}{ You've had condoms in the last year? } & No & 404 & $64.8(60.1-69.5)$ \\
\hline & Yes & 219 & $35.2(28.9-41.5)$ \\
\hline \multirow{2}{*}{$\begin{array}{l}\text { Have you participated in any talk, talk } \\
\text { wheel or information workshop on } \\
\text { HIV/AIDS and other STIs in the last year? }\end{array}$} & No & 284 & $45.6(39.8-51.4)$ \\
\hline & Yes & 339 & $54.4(49.1-59.7)$ \\
\hline
\end{tabular}

CI - Confidence Interval

Source: Search data (2020).

Regarding knowledge related to sexually transmitted forms of infection, $95.3 \%$ of the interviewees reported that a person can contract AIDS by having sex without a condom; $83.6 \%$ believe that the mother can transmit the AIDS virus during pregnancy or childbirth to the baby; $61.8 \%$ stated that a baby can catch AIDS when receiving contaminated breast milk; $96.1 \%$ answered that contaminated blood transfusion is also a means to acquire AIDS, as well as the sharing of contaminated syringes $(95.8 \%) ; 87 \%$ of teenagers agree that a child does not contract AIDS simply by playing with another child with the virus (Table 3). 
Table 3 - Distribution of absolute values and percentages of variables related to QASP questionnaire knowledge, Natal, 2020.

\begin{tabular}{|c|c|c|c|}
\hline Variable & Category & $\mathbf{N}$ & $\%(\mathrm{IC} 95 \%)$ \\
\hline \multirow{2}{*}{$\begin{array}{l}\text { Do you think a person can get aids if they have sex without } \\
\text { a condom? }\end{array}$} & NO & 29 & $4.7(0.0-12.4)$ \\
\hline & YES & 594 & $95.3(93.6-97.0)$ \\
\hline \multirow{2}{*}{$\begin{array}{l}\text { Do you think a person can catch AIDS if they use the same } \\
\text { cutlery. plates and glasses as someone who has AIDS? }\end{array}$} & YES & 262 & $42.1(36.1-48.1)$ \\
\hline & NO & 361 & $57.9(52.8-63.0)$ \\
\hline \multirow{2}{*}{$\begin{array}{l}\text { Do you think a person can catch aids if they kiss on the } \\
\text { mouth a person who has the AIDS virus? }\end{array}$} & YES & 319 & $51.2(45.7-56.7)$ \\
\hline & NO & 304 & $48.8(43.2-54.4)$ \\
\hline \multirow{2}{*}{$\begin{array}{l}\text { Do you think a person can get AIDS if they use the same } \\
\text { bathroom that someone who has AIDS uses? }\end{array}$} & YES & 234 & $37.6(31.4-43.8)$ \\
\hline & NO & 389 & $62.4(57.6-67.2)$ \\
\hline \multirow{2}{*}{$\begin{array}{l}\text { During pregnancy or childbirth. the mother can pass the } \\
\text { AIDS virus to the child? }\end{array}$} & NO & 102 & $16.4(9.2-23.6)$ \\
\hline & YES & 521 & $83.6(80.4-86.8)$ \\
\hline \multirow{2}{*}{$\begin{array}{l}\text { A baby can get AIDS when receiving breast milk from a } \\
\text { woman who has the AIDS virus? }\end{array}$} & NO & 238 & $38.2(32.0-44.4)$ \\
\hline & YES & 385 & $61.8(56.9-66.7)$ \\
\hline \multirow[t]{2}{*}{ A person can catch AIDS by mosquito-like insect bites? } & YES & 207 & $33.2(26.8-39.6)$ \\
\hline & NO & 416 & $66.8(62.3-71.3)$ \\
\hline \multirow{2}{*}{$\begin{array}{l}\text { A person can get AIDS if they receive blood contaminated } \\
\text { by the AIDS virus? }\end{array}$} & $\mathrm{NO}$ & 24 & $3.9(0.0-11.6)$ \\
\hline & YES & 599 & $96.1(94.5-97.7)$ \\
\hline \multirow{2}{*}{$\begin{array}{l}\text { A person can become infected with the AIDS virus if they } \\
\text { use the same syringe and needle that someone else used? }\end{array}$} & NO & 26 & $4.2(0.0-11.9)$ \\
\hline & YES & 597 & $95.8(94.2-97.4)$ \\
\hline \multirow{2}{*}{$\begin{array}{l}\text { A child can get AIDS if they play with another child who } \\
\text { has the virus? }\end{array}$} & YES & 81 & $13.0(5.7-20.3)$ \\
\hline & NO & 542 & $87.0(84.2-89.8)$ \\
\hline
\end{tabular}

\section{CI - Confidence Interval}

Source: Search data (2020).

Regarding sexual practices, $50.7 \%$ of teenagers reported having already had their first sexual intercourse. The age of initiation to sexual practice ranged from 9 to 18 years, with predominance of those in the age group between 14 and 17 (78.9\%). Regarding condom use in the first relationship, the majority reported having used (61.1\%), however, of those who keep sexuality active in the last six months, only 31.3\% used condoms. Most reported not having sex with more than six people in the last six months $(70.9 \%)$ and $62.7 \%$ reported having sex with a steady partner. Most of them also answered that they had not paid to have sex with someone (70.9\%) (Table 4). 
Table 4 - Distribution of absolute values and percentages of adolescents who started sexual practice in relation to contextual questions of the questionnaire QASP (N=316). Natal. 2020.

\begin{tabular}{|c|c|c|c|}
\hline Variable & Category & $\mathbf{N}$ & $\%(\mathrm{CI} 95 \%)$ \\
\hline \multirow[t]{2}{*}{ Have you ever had sex? } & YES & 316 & $50.7(45.2-56.2)$ \\
\hline & NO & 307 & $49.3(43.7-54.9)$ \\
\hline \multirow[t]{4}{*}{ How old were you when you first had sex? } & 9 to 13 & 43 & $13.6(3.4-23.8)$ \\
\hline & 14 to 17 & 249 & $78.9(73.8-84.0)$ \\
\hline & 18 & 2 & $0.6(0.0-11.3)$ \\
\hline & DIDN'T ANSWER & 22 & $7.0(0.0-17.7)$ \\
\hline \multirow[t]{3}{*}{ You used a condom when you first had sex? } & YES & 193 & $61.1(54.2-68.0)$ \\
\hline & NO & 118 & $37.3(28.6-46.0)$ \\
\hline & DIDN'T ANSWER & 5 & $1.6(0.0-12.6)$ \\
\hline \multirow[t]{3}{*}{ You've had sex in the last six months? } & YES & 243 & $76.9(71.6-82.2)$ \\
\hline & NO & 68 & $21.5(11.7-31.3)$ \\
\hline & DIDN'T ANSWER & 5 & $1.6(0.0-12.6)$ \\
\hline \multirow[t]{3}{*}{ You've had a condom every time in the last six months? } & YES & 99 & $31.3(22.2-40.4)$ \\
\hline & NO & 144 & $45.6(37.5-53.7)$ \\
\hline & DIDN'T ANSWER & 73 & $23.1(13.4-32.8)$ \\
\hline \multirow{3}{*}{$\begin{array}{l}\text { Have you had sex with more than six people in the last six } \\
\text { months? }\end{array}$} & SIM & 19 & $6.0(0.0-16.7)$ \\
\hline & NO & 224 & $70.9(65.0-76.8)$ \\
\hline & DIDN'T ANSWER & 73 & $23.1(13.4-32.8)$ \\
\hline \multirow{3}{*}{$\begin{array}{l}\text { Have you had sex with someone you consider a steady } \\
\text { partner or steady partner. i.e.. husband. wife. companion. } \\
\text { companion. groom. bride. boyfriend. girlfriend or lover? }\end{array}$} & YES & 198 & $62.7(56.0-69.4)$ \\
\hline & NO & 45 & $14.2(4.0-24.4)$ \\
\hline & DIDN'T ANSWER & 73 & $23.1(13.4-32.8)$ \\
\hline \multirow[t]{3}{*}{ Your last fuck with this person was using a condom? } & YES & 91 & $28.8(16.5-38.1)$ \\
\hline & NO & 106 & $33.5(24.5-42.5)$ \\
\hline & DIDN'T ANSWER & 119 & $37.7(29.0-46.4)$ \\
\hline \multirow{3}{*}{$\begin{array}{l}\text { You've had sex with someone you consider an eventual } \\
\text { partner or scheme. i.e. someone you've been with? }\end{array}$} & YES & 139 & $44.0(35.7-52.3)$ \\
\hline & NO & 102 & $32.3(23.2-41.4)$ \\
\hline & DIDN'T ANSWER & 75 & $23.7(14.1-33.3)$ \\
\hline \multirow[t]{3}{*}{ Your last fuck with this person was wearing a condom.? } & YES & 80 & $25.3(15.8-34.8)$ \\
\hline & NO & 58 & $18.4(8.4-28.4)$ \\
\hline & DIDN'T ANSWER & 178 & $56.3(49.0-63.6)$ \\
\hline \multirow[t]{3}{*}{ In the last six months. you've paid to have sex with someone? } & YES & 9 & $2.8(0.0-13.6)$ \\
\hline & NO & 224 & $70.9(65.0-76.8)$ \\
\hline & DIDN'T ANSWER & 83 & $26.3(16.8-35.8)$ \\
\hline \multirow{3}{*}{$\begin{array}{l}\text { In the last six months you've received money. drugs or gift to } \\
\text { have sex with someone? }\end{array}$} & YES & 7 & $2.2(0.0-13.1)$ \\
\hline & NO & 235 & $74.4(68.8-80.0)$ \\
\hline & DIDN'T ANSWER & 74 & $23.4(13.8-33.0)$ \\
\hline \multirow[t]{3}{*}{ Your last fuck with this person was wearing a condom.? } & YES & 3 & $0.9(0.0-11.6)$ \\
\hline & $\mathrm{NO}$ & 4 & $1.3(0.0-12.4)$ \\
\hline & DIDN'T ANSWER & 309 & $97.8(96.2-99.4)$ \\
\hline \multirow{3}{*}{$\begin{array}{l}\text { You've had some kind of penis or vagina wound in the last } \\
\text { six months.? }\end{array}$} & YES & 11 & $3.5(0.0-14.4)$ \\
\hline & NO & 225 & $71.2(65.3-77.1)$ \\
\hline & DIDN'T ANSWER & 80 & $25.3(15.8-34.8)$ \\
\hline \multirow{3}{*}{$\begin{array}{l}\text { You sought the health service because of the wound in the } \\
\text { penis or vagina? }\end{array}$} & YES & 4 & $1.3(0.0-12.4)$ \\
\hline & $\mathrm{NO}$ & 8 & $2.5(0.0-13.3)$ \\
\hline & DIDN'T ANSWER & 304 & $96.2(94.1-98.3)$ \\
\hline \multirow{3}{*}{$\begin{array}{l}\text { You've had some runrun through the urine canal in the last } \\
\text { six months }\end{array}$} & YES & 31 & $9.8(0.0-20.3)$ \\
\hline & NO & 190 & $60.1(53.1-67.1)$ \\
\hline & DIDN'T ANSWER & 95 & $30.1(20.9-39.3)$ \\
\hline \multirow{3}{*}{$\begin{array}{l}\text { You went to the health service because of the discharge } \\
\text { through the urine canal? }\end{array}$} & YES & 15 & $4.7(0.0-15.4)$ \\
\hline & NO & 21 & $6.6(0.0-17.2)$ \\
\hline & DIDN'T ANSWER & 280 & $88.6(84.9-92.3)$ \\
\hline \multirow[t]{3}{*}{ You used alcohol the last time you had sex? } & YES & 49 & $15.5(5.4-25.6)$ \\
\hline & NO & 180 & $57.0(49.8-64.2)$ \\
\hline & DIDN'T ANSWER & 87 & $27.5(18.1-36.9)$ \\
\hline You used some drugs the last time you had sex? Marijuana or & YES & 21 & $6.6(0.0-17.2)$ \\
\hline cocaine or crack or other drug? & NO & 218 & $69.0(62.9-75.1)$ \\
\hline & DIDN'T ANSWER & 77 & $24.4(14.8-34.0)$ \\
\hline
\end{tabular}

CI - Confidence Interval.

Source: Search data (2020). 


\section{Discussion}

The present study aimed to evaluate the knowledge, attitudes and practices of school teenagers about their sexuality. Its results become essential in planning and decision-making regarding the sexual education provided to this public. Although positive results were found regarding the interviewees' knowledge about the prevention of HIV/AIDS and other STIs, conflicting statistics were identified regarding the practices adopted by them.

Female participants obtained a higher average of success regarding knowledge and practices tangent to HIV, which agrees with the existing literature where it is observed that men are more vulnerable about the risks regarding STIs in relation to women, since they have their first relationship earlier (Scoralick et al., 2018). Still aware of the fact that, in a casual way, girls discuss sexuality with friends and new acquaintances and choose a stable partner or boyfriend to perform the first sexual intercourse (Oliveira et al., 2018). Boys also have more sexual partners than girls (Costa, Silva \& Nascimento, 2018).

They also obtained higher averages of success those with a partner, attending the 2nd year, white and receiving financial aid from the federal government. Hartmann and Cesar (2013) suggest that belonging to the female gender, having a lower age, low schooling and lower family income, being single and without a girlfriend are factors associated in isolation with the non-knowledge of a male condom.

Young people with lower schooling reported the onset of earlier sexual activity, while students with higher schooling showed greater concern about becoming infected with some STIs and also a higher level of knowledge related to the subject, using condoms more frequently, both in the first and most recent sexual intercourse (Miranda et al., 2013).

Observing the questions about knowledge and practices in isolation, most of the interviewees correctly mentioned the possibility of HIV transmission during condom sex, during pregnancy, childbirth or breastfeeding, by blood transfusion as well as the sharing of contaminated syringes; and agree that a child does not catch AIDS while playing with another child carrying the virus.

The findings of this study corroborate with Silva et al. (2016), where it was demonstrated that when asked if HIV infection is possible through the shared use of needles and syringes, regarding the vertical transmission of HIV and the transmission of HIV through breast milk, most stated that they knew about the possibility of transmission.

Regarding the educational activities related to the theme HIV/AIDS and other STIs, most of the students reported having participated in some educational action, developed in the school itself, by teachers or other social programs, and a significant portion of the interviewees received informative materials in relation to STIs. The findings compare a previous study, which showed that most teenagers did not obtain guidance on HIV/AIDS at school (Silva et al., 2016), which makes them susceptible to receiving wrong or incomplete information with friends or partners who also do not have sufficient knowledge (Santos \& Nogueira, 2019).

Angelim et al. (2016) point to the importance of conducting information workshops during the learning process of students, promoting moments of discussion and reflection on the attitudes of students towards risk factors, symptoms, prevention and forms of transmission of HIV/AIDS and other STIs, in addition, the need to stimulate the support of safe sexual behaviors.

Most of the participants in this study stated that, although they received information about STIs, condoms were not given condoms, which is an important point to note because a significant portion of teenagers suggests that the realization of educational campaigns on HIV/AIDS and other STIs, and the delivery of condoms by municipal health centers, would be a positive practice in the prevention of these infections. Since the lectures considerably expanded the interviewees' knowledge about the theme in question (Costa \& Nunes, 2017).

At this juncture, it is necessary to provide a closer approximation of the school with health services, making them feel comfortable seeking help and seeking information (Ciriaco et al., 2019). Thus, these subjects may expand their autonomy for 
conscious choices. Sex education is a shared responsibility among educators, health professionals, in addition to parents who can have these dialogues when they feel comfortable and able to talk to their children about the subject (Queiroz et al., 2016).

About sexual practices, most teenagers reported having already had their first sexual intercourse. The age of initiation to sexual practice ranged from 9 to 18 years old, with predominance of those in the age group between 14 and 17 . The findings corroborate the literature, which indicates that the average age at the beginning of sexual life corresponded to 14, ranging from 12 to 17 for girls and 7 to 16 for boys. And that most students had their first sexual intercourse in the interval between 13 and 15 , and condom use was reported by only $39 \%$ of them (Souza, 2018).

Regarding condom use in the first relationship, the majority reported having used, however, those who maintain active sexuality in the last six months, most reported not using condoms. This fact agrees with the literature, where it is verified that most sexually active young people used the insum in the first sexual intercourse (Moreira, Dumith \& Paludo, 2018).

Regarding risky sexual behavior, the higher proportion prefers to maintain sexual practice with fixed partners and use condoms as a means of preventing STIs. However, a significant portion prevails that does not use condoms in sexual activities, which may be linked to the result that states that most respondents prefer a monogamous relationship, because the relationship of trust and proximity between partners can contrast with the use of condoms about safe sex (Flores, 2016).

Condom use permeates social construction, to which men are conditioned to reject the idea of condoms as a form of sexual reaffirmation. Thus, they may react negatively or violently when they are pressured to use (Martins et al., 2020). Therefore, there remains the need to understand why we do not agree, because through these answers, guidance strategies can be created on the benefit of condom use, with a view to consolidating the theme for all people, especially those teenagers who least ingress (Souza, 2018).

It is essential that health professionals with education formulate strategies to disseminate to teenagers, knowledge about HIV/AIDS and other STIs, so that they can understand safe behaviors in their sexual relations. Promptly, the construction of educational practices in schools will give teenagers the opportunity to question, engage and participate, working on their own doubts, learning about the subject and thus preventing themselves against these infections (Souza, 2018).

\section{Conclusion}

It can be concluded that the present study obtained positive results regarding the evaluation of teenagers' knowledge about the prevention of HIV/AIDS and other STIs, since most of the interviewees know the forms of transmission of these infections. However, although young people have acquired a satisfactory degree of knowledge, they insist on adopting unsafe sexual practices, especially about condom use, which decreases over the occurrence of sexual intercourse.

However, there is a whole cultural and socioeconomic context that acts as a modulator of practices, behaviors and attitudes, and interferes in the decision-making process. In this context, it is considered that this study provides relevant information for those who are involved in interventions to promote sexual and reproductive health, since it sought to evaluate the knowledge, attitudes and practices of students, and, through this analysis, reinforce the need to invest in policies and programs of sexual orientation in schools with attention focused on the integral health of teenagers, in order to prevent them from becoming involved in situations of exposure to the risks of HIV/AIDS and other STIs, considering aspects such as poverty, different cultures, social exclusion and other associated factors.

We cite as strategies to change the current scenario, the offer of continuous educational actions, coming from primary care in partnership with schools. The multidisciplinary health team, especially the nursing professional, has knowledge about the theme. In this sense, the implementation of activities aimed at promoting sexual and reproductive health, and the prevention of STIs, can contribute significantly to the adoption of safe and healthy practices by teenagers. 
As limitations, the study was conducted only with teenagers from public schools, presenting similar levels of education, making the sample homogeneous in this aspect. In this regard, it is necessary to include more heterogeneous samples in future studies. It should be noted that because it is a knowledge and practice survey, as well as a cross-sectional study, the research presents the limitation of not accompanying these young people for a period, as well as pointing out the need for new studies that seek to highlight why teenagers, even with knowledge about safe practices, insist on countering prevention, putting their own health and that of others at risk.

\section{References}

Andrade, D. F., Tavares, H. R., \& Valle, R. C. (2000). Teoria da Resposta ao Item: conceitos e aplicações. SINAPE.

Angelim, R. C. M., et al. (2016). Atividades educativas sobre práticas sexuais de risco para estudantes: relato de experiência. Revista de Enfermagem da Universidade Federal do Piauí (REUFPI), 5(1), 96-100.

Brasil. (2011). Pesquisa de conhecimento, atitudes e práticas na população brasileira. Ministério da Saúde.

Brasil. (2010). PNUD Brasil. Índice de Desenvolvimento Humano Municipal, 2010 - Todos os Estados do Brasil. https://www.br.undp.org/content/b razil/pt/home/idh0/ranki ngs/idhm-uf-2010.html.

Brasil. (2013). Resolução $n^{\circ}$ 466, de 12 de dezembro de 2012. Dispõe sobre diretrizes e normas regulamentadoras de pesquisas envolvendo seres humanos. Diário Oficial da República Federativa do Brasil, Brasília, Distrito Federal, Brasil.

Brasil. (2016). Pesquisa Nacional de Saúde do Escolar. Ministério da Saúde.

Cabrera-Garcia, V., Docal-Millán, M. D., Manrique-Mora, L. M., Piraquive, J. M., \& Aguilar, C. M. (2018). Family and school: contexts associated with the onset of sexual activity among colombian teenagers. Revista de Salud Pública, 20(3), 279-85.

Ciriaco, N. L. C., Pereira, L. A. A. C., Campos, P. H. A., \& Costa, R. A. (2019). A importância do conhecimento sobre Infecções Sexualmente Transmissíveis (IST) pelos adolescentes e a necessidade de uma abordagem que vá além das concepções biológicas. Em Extensão, 18(1), 63-80.

Cordeiro, J. K. R., Santos, M. M., Sales, LK. O., Morais, I. F., \& Dutra, G. R. S. F. (2017). Adolescentes escolares acerca das DST/aids: quando o conhecimento não acompanha as práticas seguras. Revista de Enfermagem UFPE on line, 11(7), 2888-96.

Costa, I. D. N., \& Nunes, N. S. (2017). Compreensão dos adolescentes sobre a prevenção e transmissão das infecções sexualmente transmissíveis em escolas do município de presidente Médici, Rondônia, Brasil. Acta Biomedica Brasiliensia, 8(1), 12-23.

Costa, R. S. L., Silva, W. B. Nascimento, \& K. J. O. (2018). Percepção de risco de adolescentes escolares em relação às infecções sexualmente transmissíveis em duas escolas de ensino médio do Acre. DêCiência em Foco, 2(2), 59-72.

Costa,M. I. F., Rodrigues, R. R., Teixeira, R. M., Paula, P. H. A., Luna, I. T., Pinheiro, P. N. C. (2020). Adolescentes em situação de pobreza: resiliência e vulnerabilidades às infecções sexualmente transmissíveis. Revista Brasileira de Enfermagem, 73.

Costenaro, R. G. S., Jesus, M. I. A., Oliveira, P. P., Roos, M. O., Stankowski, S. S., \& Teixeira, D. A. (2020). Sexual Education With Adolescents: promoting health and socializing good social and family practices. Brazilian Journal of Development, 6 (12), 544-60.

Etikan, I., \& Bala, K. (2017). Combination of Probability Random Sampling Method with Non Probability Random Sampling Method (Sampling Versus Sampling Methods). Biometrics \& biostatistics international Journal, 5(6), 148.

Ferrari, W., Peres, S., \& Nascimento, M. (2018). Experimentação e aprendizagem na trajetória afetiva e sexual de jovens de uma favela do Rio de Janeiro, Brasil, com experiência de aborto clandestino. Ciência e Saúde Coletiva, 23(9), 2937-50.

Flores, Y. Y. R. (2016). A violência sexual como fator limitante na percepção e gestão do risco de HIV em mulheres casadas com migrantes. Revista LatinoAmericana de Enfermagem, 24, e2782.

Fonseca, R. M. G. S., Santos, D. L. A., Gessner, R., Fornari, L. F., Oliveira, R. N. G., \& Schoenmaker, M. C. (2018). Gênero, sexualidade e violência: percepção de adolescentes mobilizadas em um jogo online. Revista Brasileira de Enfermagem, 71(1), 652-59.

Hartmann, J. M., \& Cesar, J. A. (2013). Conhecimento de preservativo masculino entre adolescentes: estudo de base populacional no semiárido nordestino, Brasil. Cadernos de Saúde Pública, 29(11), 2297-2306.

Malta, D. C., Andreazzi, M. A. R., Oliveira-Campos, M., Andrade, S. S. C. A., Sá, N. N. B., Dias, L. M. A. J. R., Crespo, C. D., \& Silva, J. B. (2014). Tendências dos fatores de risco e proteção de doenças crônicas não transmissíveis em adolescentes, pesquisa nacional de saúde do escolar (PeNSE 2009 e 2012). Revista Brasileira de Epidemiologia, 17(1), 77-91.

Martins, E. R. C., Medeiros, A. S., Oliveira, K. L., Fassarella, L. G., Moraes, P. C., \& Spíndola T. (2020). Vulnerabilidade de homens jovens e suas necessidades de saúde. Escola Anna Nery Revista de Enfermagem, 24(1), e20190203.

Miranda, A. E., Ribeiro, D., Rezende, E. F., Pereira, G. F. M., Pinto, V. M., \& Saraceni, V. (2013). Associação de conhecimento sobre DST e grau de escolaridade entre conscritos em alistamento ao Exército Brasileiro. Ciência \& Saúde Coletiva, 18(2), 489-97. 
Research, Society and Development, v. 10, n. 13, e491101321468, 2021

(CC BY 4.0) | ISSN 2525-3409 | DOI: http://dx.doi.org/10.33448/rsd-v10i13.21468

Moita Neto, J. M. (2004). Estatística multivariada: Uma visão didática-metodológica. Filosofia da Ciência, 1-13.

Moreira, L. R., Dumith, S. C., Paludo, S. S. (2018). Uso de preservativos na última relação sexual entre universitários: quantos usam e quem são?. Ciência \& Saúde Coletiva, 23(4), 1255-66.

Neves, R. G., Wendt, A., Flores, T. R., Costa, C. S., Costa, F. S., Tovo-Rodrigues, L., \& Nunes, B. P. (2017). Simultaneidade de comportamentos de risco para infecções sexualmente transmissíveis em adolescentes brasileiros, 2012. Epidemiologia e Serviços de Saúde, 26(3), $443-54$.

Oliveira, P. S., Abud, A. C. F., Inagaki, A. D. M., Alves, J. A. B., \& Matos, K. F. (2018). Vulnerabilidade de adolescentes às doenças sexualmente transmissíveis na atenção primária. Revista de Enfermagem UFPE on line, 12(3), 753-62.

Pinto, V. M., Basso, C. R., Barros, C. R. S., \& Gutierrez, E. B. (2018). Fatores associados às infecções sexualmente transmissíveis: inquérito populacional no município de São Paulo, Brasil. Ciência \& Saúde Coletiva, 23(7), 2423-32.

Queiroz, M. V. O., Alcântara, C. M., Brasil, E. G. M., \& Silva, R. M. (2016). Participação de adolescentes em ações educativas sobre saúde sexual e contracepção. Revista Brasileira em Promoção da Saúde (RBPS), 29, 58-65.

Rodrigues, M. T. P, Moreira, T. M. M., Vasconcelos, A. M., Andrade, D. F., Silva, D. B., \& Barbetta, P. A. (2013). Instrumento mensurador de adesão para hipertensos: contribuição da Teoria da Resposta ao Item. Revista de Saúde Pública, 47(3), 523-30.

Santos, C. A. C., \& Nogueira, K. T. (2019). Gravidez na adolescência: falta de informação? Revista Adolescência e Saúde, 6(1), 48-56.

Scoralick, G. B. F., Daher, D. V., Faria, M. G. A., Brito, I. S., Sabóia, V. M., \& Guimarães, M. R. (2018). Análise do Comportamento Sexual de Adolescentes e Fatores de Risco à Saúde. Revista Enfermagem Atual, 86(24).

Silva, R. A. R., Nelson, A. R. C., Duarte, F. H. S., Prado, N. C. C., Holanda, J. R. R., \& Costa, D. A. R. S. (2016). Conhecimento de estudantes adolescentes sobre transmissão, prevenção e comportamentos de risco em relação as DST/HIV/AIDS. Journal of Research: Fundamental Care Online's, 8(4), 5054-61.

Souza L. S. (2018). Conhecimentos e práticas de adolescentes acerca das Infecções Sexuais Transmissíveis (ISTs) nas escolas públicas do município de Aracaju/SE. Sergipe. Trabalho de Conclusão de Curso - Universidade Federal de Sergipe.

Zompero, A. F., Leite, C. M., Giangarelli, D. C., \& Bermago, M. C. (2018). A temática sexualidade nas propostas Curriculares no Brasil. Revista Ciências \& Ideias, 9(1), 101-14. 